Pontificia Universidade Catoìlica do Rio de Janerio, and a BA from Pontificia Universidade Catoilica de Minas Gerais.

Omar Wasow joined the Princeton University political science faculty on September 1, 2013, after coming to Princeton as a senior research assistant and postdoctoral research associate. A specialist in race and ethnic politics and American political development, Wasow earned his bachelor's degree at Stanford and his PhD at Harvard.

Judithanne Scourfield McLauchlan, professor of political science and law at the University of South Florida, St. Petersburg, has declared her candidacy for the State Senate in Florida's 22nd District, composed of parts of Pinellas and Hillsborough counties. McLauchlan is a Fulbright Scholar, served on the board of directors for the League of Women Voters, and is a longtime Democratic operative. She will face incumbent Jeff Brandes, a Republican, in a district that has voted for Democratic candidates in the past several elections.

\section{ADMINISTRATIVE APPOINTMENTS}

Christopher J. Deering, senior associate dean and associate provost, George Washington University Science and Technology Campus

\section{A W AR D S}

Bruce Buchanan, professor, department of government, The University of Texas at Austin, the Fall 2013 Silver Spurs Centennial Teaching Fellowship

Donald P. Haider-Markel, professor and chair, department of political science, University of Kansas, 2013 University Scholarly Achievement Award (a University-wide research award)

John Kennedy, associate professordepartment of political science and East Asian Studies Program, University of Kansas was awarded the Gene A. Budig Teaching Professorship Award, 2013-14

\section{Books by Our Readers}

SPOTLIGHTS

The Global President: International Media and the U.S. Government

Stephen J. Farnsworth, S. Robert Lichter, and Roland Schatz

Rowman and Littlefield

From the publisher: Stephen J. Farnsworth, S. Robert Lichter, and Roland Schatz provide an expansive international examination of news coverage of US political communication and the roles the US government and the presidency play in an increasingly communicative and interconnected political world. This comprehensive yet concise text will engage and inform students in many intersecting disciplines, as it includes analyses of not just the presidency, but US foreign policy and contemporary political media itself. The media developed to keep pace with the headwinds of political change are being asked more and more to adapt to and enhance the ways in which policy-makers, voters, and students make sense of the process of governance. The realities of an ever-changing political landscape are magnified nowhere more greatly than in the realm of foreign policy, and the stakes surrounding the need for quality communicational skills are no higher than at 1600 Pennsylvania Avenue because-when the voices of the US government speakthe world is listening. This book provides students a perfect entry point into the complex and amorphous relationship between media and government, where that relationship has been, and where it looks to be heading in the future.

Stephen J. Farnsworth is professor of political science and international affairs at the University of Mary Washington and Director of the University's Center for Leadership and Media Studies. He is the author or coauthor of several books on media and politics and a former daily newspaper journalist.

S. Robert Lichter is professor of communication at George Mason University, where he directs the Center for media and Public Affairs, a nonprofit, nonpartisan media research organization.

Roland Schatz is the president of the New York-based Media tenor Ltd., a provider of international media content analysis.

Subsidizing Democracy: How Public Funding Changes Elections and How It Can Work in the Future

Michael G. Miller

Cornell University Press

From the publisher: In Subsidizing Democracy, Michael G. Miller considers the impact of state-level public election financing on political campaigns through the eyes of candidates. Miller's insights are drawn from survey data obtained from more than 1,ooo candidates, elite interview testimony, and twenty years of election data. This book is therefore not only an effort to judge the effects of existing public election funding but also a study of elite behavior, campaign effects, and the structural factors that influence campaigns and voters.

The presence of publicly funded candidates in elections, Miller reports, results in broad changes to the electoral system, including more interaction between candidates and the voting public and significantly higher voter participation.

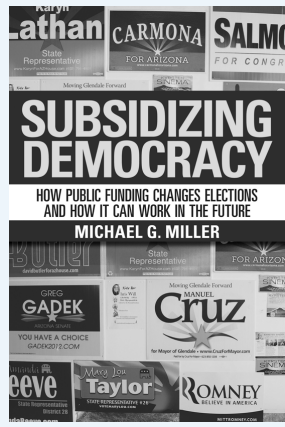

Michael G. Miller is assistant professor in the Department of Political Science and the Institute for Legal, Legislative and Policy Studies at the University of Illinois, Springfield. 
Outsiders No More? Models of Immigrant Political Incorporation Jennifer Hochschild, Jacqueline Chattopadhyay, Claudine Gay, and Michael Jones-Correa, Editors

Oxford University Press

From the publisher: Outsiders No More? brings together a multidisciplinary group of scholars to consider pathways by which immigrants may be incorporated into the political processes of western democracies. At a time when immigrants are increasingly significant political actors in many democratic polities, this volume makes a timely and valuable intervention by pushing researchers to articulate causal dynamics, provide clear definitions and measurable concepts, and develop testable hypotheses. By including historians, sociologists, and political scientists, by ranging across North America and Western Europe, by addressing successful and failed incorporative efforts, this handbook offers guides for anyone seeking to develop a dynamic, unified, and supple model of immigrant political incorporation.

Jennifer Hochschild is Henry LaBarre Jayne Professor of Government, Professor of African and African American Studies, and Harvard College Professor at Harvard University.

Jacqueline Chattopadhyay is Assistant Professor in the Department of Political Science and Public Administration at the University of North Carolina at Charlotte.

Claudine Gay is Professor of Government and of African and African-American Studies at Harvard University Michael Jones-Correa is Professor of Government at Cornell University.

America's War on Terror: The State of the 9/11 Exception from Bush to Obama

Jason Ralph

Oxford University Press

The Color of Our Shame: Race and Justice in Our Time

Christopher J. Lebron

Oxford University Press

Confluence of Thought: Mahatma Gandhi and Martin Luther King, Jr.

Bidyut Chakrabarty, Foreword by

Clayborne Carson

Oxford University Press

Counting Civilian Casualties: An Introduction to Recording and Estimating Nonmilitary Deaths in Conflict Taylor B. Seybolt, Jay D. Aronson, and Baruch Fischhoff, editors

Oxford University Press

The Effective Presidency: Lessons on Leadership from John F. Kennedy to Barack Obama

Erwin C. Hargrove

Paradigm Publishers

Eleventh Hour: The Politics of Policy

Initiatives in Presidential Transitions

Davide M. Shafie

Texas A \& M University Press
Exploitation and Economic Justice in the Liberal Capitalist State

Mark R. Rieff

Oxford University Press

The Gingrich Senators: The Roots of

Partisan Warfare in Congress

Sean M. Theriault

Oxford University Press

The Kennedy Half Century: The

Presidency, Assassination, and the Lasting

Legacy of John. F. Kennedy

Larry J. Sabato

Bloomsbury USA

The Limits of Electoral Reform

Shaun Bowler and Todd Donovan

Oxford University Press

A Mere Machine: The Supreme Court, Congress, and American Democracy

Anna Harvey

Yale University Press

Multilevel Citizenship

Willem Maas, editor

University of Pennsylvania Press

Practical Authority: Agency and

Institutional Change in Brazilian

Water Politics

Rebecca Neaera Abers and

Margaret E. Keck

Oxford University Press
Renegade Cities, Public Policy, and the Dilemmas of Federalism

Lori Riverstone-Newell

Lynne Rienner

First Forum Press

Revolution Stalled: The Political Limits of the Internet in the Post-Soviet Sphere

Sarah Oates

Oxford University Press

Russia vs. the EU: The Competition for Influence in Post-Soviet States

Jakob Tolstrup

Lynne Rienner, First Forum Press

The Social Evolution of International

Politics

Shiping Tang

Oxford University Press

Strong Constitutions: Social-Cognitive Origins of the Separation of Powers

Maxwell A. Cameron

Oxford University Press

The Time Is Always Now: Black Thought and the Transformation of US Democracy Nick Bromell

Oxford University Press

Tolerance: A Sensorial Orientation

of Politics

Lars Tønder

Oxford University Press

Understanding Prime-Ministerial

Performance: Comparative Perspectives

Paul Strangio, Paul 't Hart, and

James Walter

Oxford University Press

Wealth of an Empire: The Treasure

Shipments that Saved Britain and

the World

Robert Switky

Potomac Books

Who's Running America? The Obama

Reign

Thomas R. Dye

Paradigm Publishers

Why States Matter: An Introduction to State Politics

Gart Moncrief and Peverill Squire

Rowman and Littlefield

Why Taiwan Matters: Small Island, Global Powerhouse, updated edition

Shelley Rigger

Rowman and Littlefield 